\title{
Implantation of autologous fat globules in localized scleroderma and idiopathic lipoatrophy - report of five patients
}

\author{
Implante de fragmentos de lóbulos de gordura autóloga na esclerodermia \\ localizada e lipoatrofia idiopática, relato de cinco pacientes
}

Tiago Pina Zanelato
Renata Ferreira Magalhães
Giovana Marquesini ${ }^{2}$

Aparecida Machado de Moraes $^{5}$
Paula Tavares Colpas ${ }^{3}$

\begin{abstract}
A large number of diseases may cause Atrophic skin disorders are caused by a large number of diseases, some of them idiopathic and others inflammatory, in which there is loss of volume of body segments. Localized scleroderma is a rare inflammatory dermatosis, manifested by atrophic skin and subcutaneous tissue alterations. Lipoatrophy may be genetically inherited or acquired as a result of panniculitis, HIV infections or aging. Many treatments have been proposed. Results vary in the acute inflammatory phase and are scarce when sclerosis and atrophy have already been established. This article describes four cases of localized facial scleroderma and one of facial idiopathic lipoatrophy treated with implantation of autologous fat globules extracted from the infragluteal groove, without utilization of cannula aspiration, with lasting results.
\end{abstract}

Keywords: Atrophy; Scleroderma, localized; Subcutaneous fat

Resumo: Os distúrbios atróficos da pele abrangem inúmeras doenças, algumas idiopáticas e outras, inflamatórias, em que há perda do volume de segmentos do corpo. A esclerodermia localizada é uma dermatose inflamatória, rara, que pode manifestar-se com alterações atróficas da pele e tecido subcutâneo. A lipoatrofia pode ser herdada geneticamente ou adquirida relacionada a paniculites, infecç̧ão pelo HIV, ou envelhecimento. Muitos tratamentos são propostos. Os resultados são variáveis na fase inflamatória aguda e apresentam pouca resposta quando a esclerose e atrofia já estão instaladas. Descreve-se o tratamento de quatro casos de esclerodermia localizada e um de lipoatrofia idiopática, na face, tratados com enxerto de fragmentos de lóbulos de gordura autóloga extraídos sem a utilização da cânula aspirativa, com resultados duradouros.

Palavras-chave: Atrofia; Esclerodermia localizada; Gordura subcutânea

\section{INTRODUCTION}

A large number of diseases are related to atrophic and sclerodermal skin disturbances, and can be either genetic or acquired. Scleroderma is a chronic spectral disease which is defined by a series of skin alterations. In localized form it is known as morphea, which can affect adjacent muscles and bones. Its etiology is not completely understood and it is estimated that $50 \%$ of cases go into remission within 2.7 years of the onset of the disease. ${ }^{1}$ Following the initial inflammatory reaction, there is a localized progressive involvement of fibrosis, atrophy with hypo or hyperpigmentation. This disease is rare, and occurs predominantly in young adults. ${ }^{2}$ Lesions can be disfiguring, and can manifest themselves in linear forms and affect all of a hemiface with the Parry Romberg syndrome, described in $1846 .{ }^{3}$

Received on 09.09.2012.

Approved by the Advisory Board and accepted for publication on 29.10.2012.

* Work performed at the Medical School, State University of Campinas (UNICAMP) - Campinas (SP), Brazil.

Conflict of interest: None

Financial funding: None

MD, Dermatologist - Adjunct Discipline Dermatologic Surgery, Faculdade de Ciências Médicas, Universidade Estadual de Campinas (UNICAMP) - Campinas (SP), Brazil.

MD, Dermatologist - Faculdade de Ciências Médicas, Universidade Estadual de Campinas (UNICAMP) - Campinas (SP), Brazil.

MD, Dermatologist - Adjunct Department of Dermatology, Faculdade de Ciências Médicas, Universidade Estadual de Campinas (UNICAMP) - Campinas (SP), Brazil.

MD, PhD. Professor of Dermatology, Faculdade de Ciências Médicas, Universidade Estadual de Campinas (UNICAMP) - Campinas (SP), Brazil.

MD, PhD. Professor of Dermatology, Head of Dermatologic Surgery, Faculdade de Ciências Médicas, Universidade Estadual de Campinas (UNICAMP) Campinas (SP), Brazil.

C2013 by Anais Brasileiros de Dermatologia 
Several treatments have been proposed with varying results, taking into consideration the stage of the illness, age of the patient, and localization and extension of the lesions. Therapeutic options include corticosteroids, methotrexate, calcipotriol, imiquimod, tacrolimus, ultraviolet $\mathrm{A}$ and $\mathrm{CO} 2$ fractional laser treatment. ${ }^{1,2,4,5}$

Facial lipoatrophy can be genetically inherited, without specific related pathology, or can be associated with a variety of conditions, including panniculitis, HIV infection, or aging.

There are many surgical reconstructive techniques used where loss of volume to the face or other areas has occurred. Synthetic filling materials such as hyaluronic acid, calcium hydroxyapatite, and poly-llactic-acid can be used. ${ }^{7.8}$ In addition, there are reports of the use of autologous fat globules, demineralized bone matrix, and flaps. ${ }^{9,10}$

This study presents patients treated with the implantation of autologous fat globules with septa of connective tissue, extracted without cannula aspiration, and producing long-term results.

\section{CASE REPORT}

The authors report one case of facial idiopathic lipoatrophy in a male patient and four cases of scleroderma in two males and two female patients from 17 to 26 years of age, all presenting linear lesions and atrophy on the face, without inflammation and stable in their dimensions (Figure 1). The cases of facial scleroderma correspond clinically to Romberg syndrome.

The patients were admitted to the medical facility on the day of the surgery and released the same day.

The infragluteal fold was chosen as the donor site. Following sterilization with ipovidone iodine scrub (PVP-I), the patients were anesthetized with $2 \%$ lidocaine applied to one infragluteal fold per session. An incision of approximately $5 \mathrm{~cm}$ was made in the skin, dissected to the subcutaneous tissue from which the fragments of fat were taken with the use of anatomical forceps and iris scissors. Internal and external sutures were used to close the incision, using 4-0 nylon thread. The fragments were processed in small dimensions of approximately $0.3 \mathrm{~cm}$, and stored in a refrigerated saline solution (Figure 2).

Preparations were begun at the receiving site with localized scleroderma. Anesthetic infiltration with 1\% lidocaine or locoregional anesthetic block was injected, for example in the malar region. A small incision of approximately $0.5 \mathrm{~cm}$ was made, preferably on the margin of the lesion. Through this small opening, the sclerotic area was carefully peeled from a deep level, using scissors and a grooved probe, creating a space beneath the sclerodermal lesion (Figure 3).
A $60 \mathrm{ml}$ urological syringe was used to decant the material and introduce the receptor into the space, under light pressure (Figure 2). After filling the space to the point of improving the appearance of atrophy, the small incision was sutured and the necessary bandages applied to the region (Figure 4). Antibiotic therapy was prescribed for 7 days. Ablation occurred from 7-10 days in the receptor region and 14 days at the donor site (Figure 5).
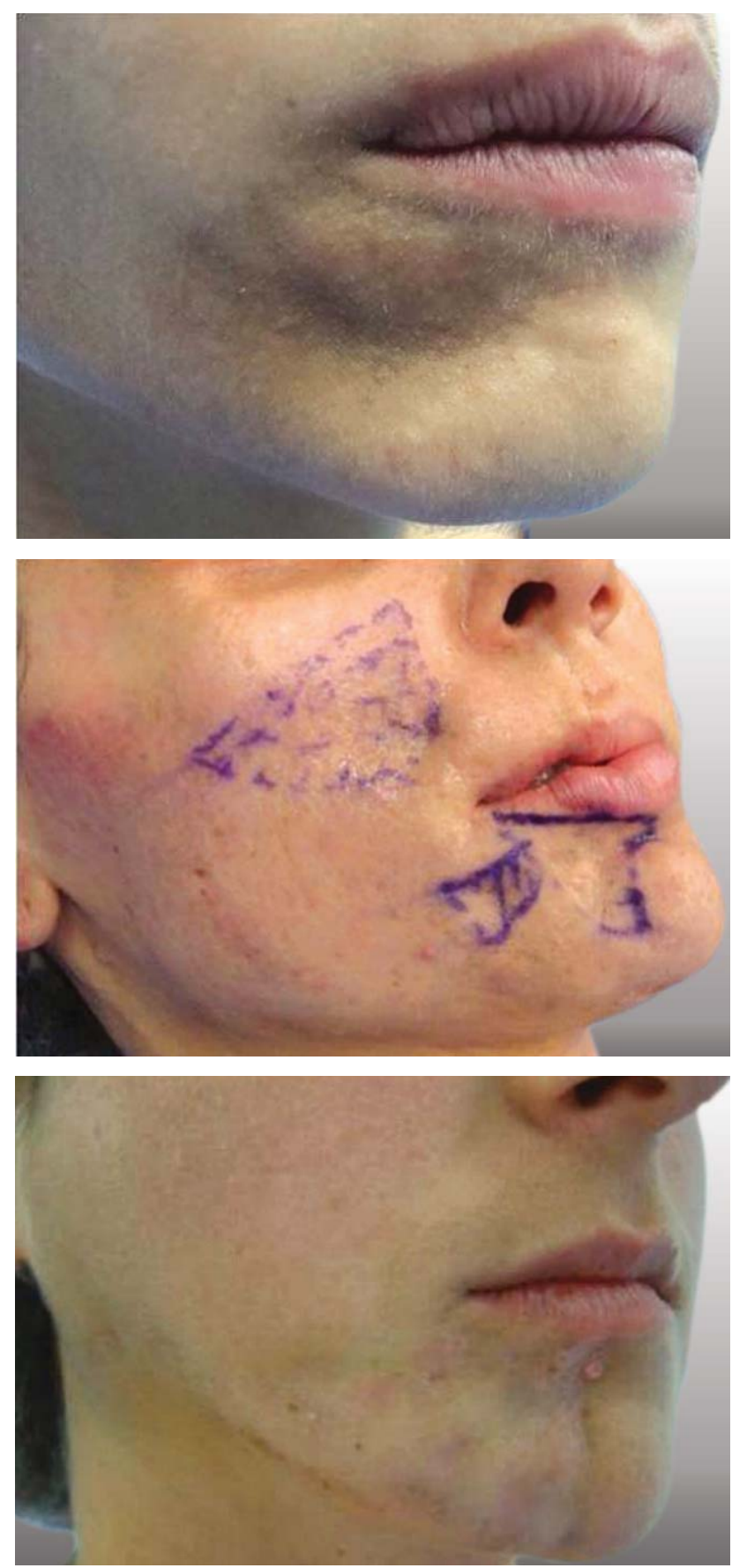

FIGURE 1: Cases of scleroderma lesions and atrophy on the face 

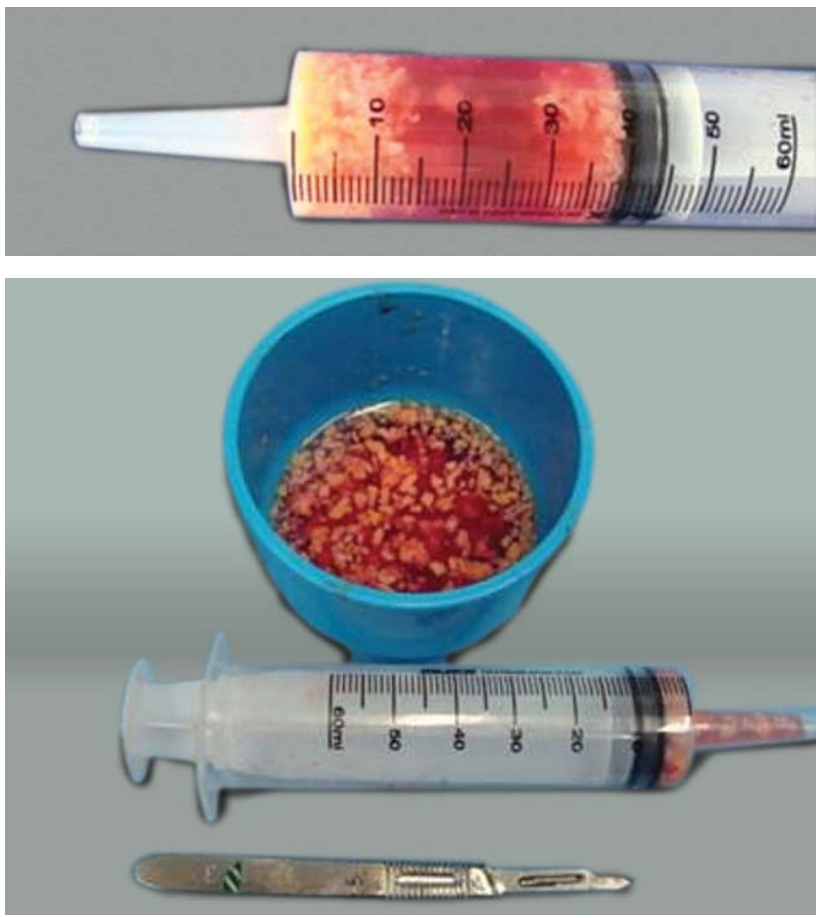

FIGURE 2: Fragments of fat processed in small dimensions

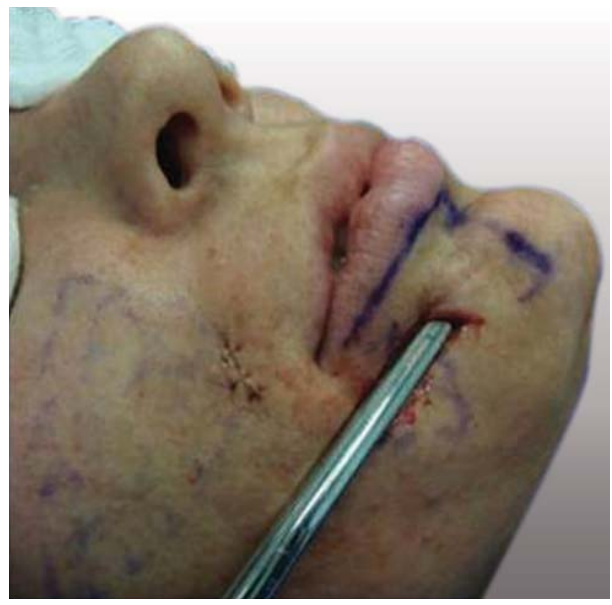

Figure 3: The sclerotic area was carefully peeled from a deep level

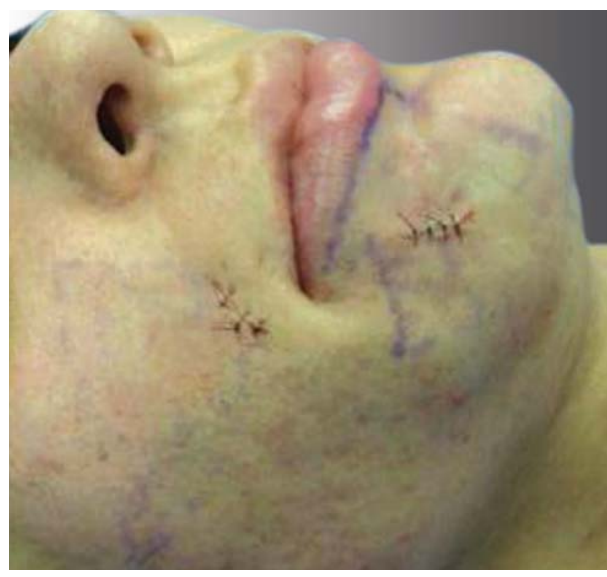

Figure 4: After filling, the small incision was sutured
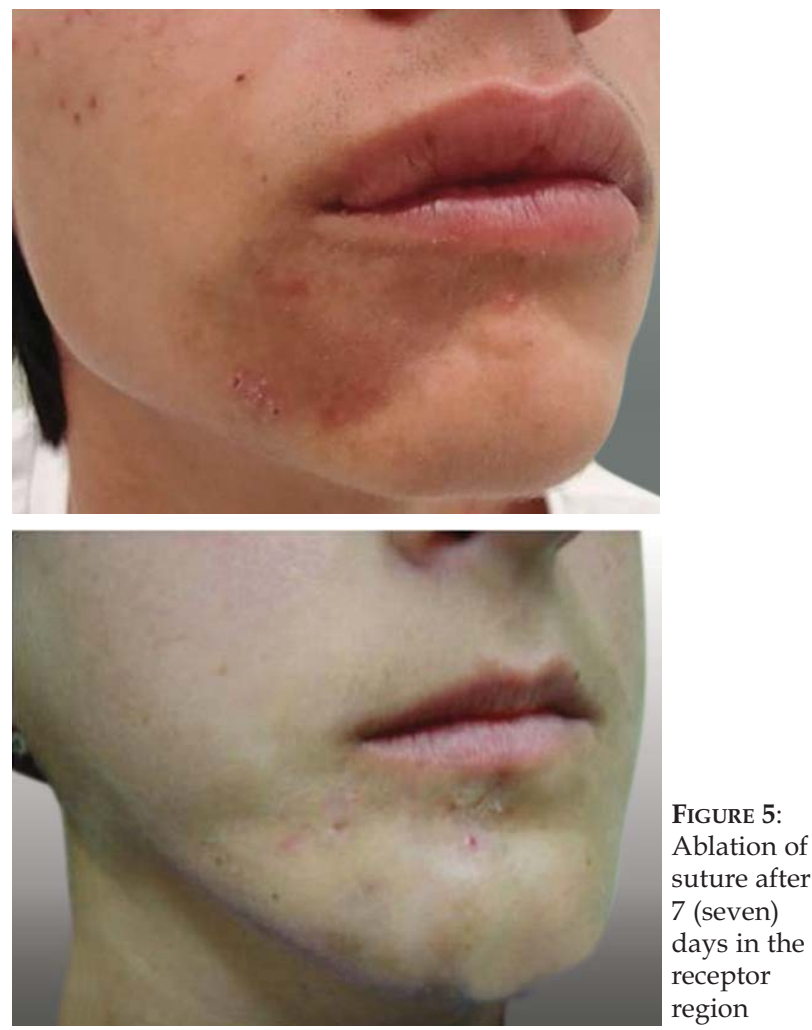

\section{DISCUSSION}

Autologous fat transplants are utilized in a series of conditions in which there is loss of local volume. The materials available for correction of scleroatrophy have become restricted because there is always the possibility that their composition or molecular fragments will cause adverse reactions and worsen the disease. ${ }^{6}$

Corrections of localized scleroderma and idiopathic lipodystrophy are important to patients because these diseases can manifest in a disfiguring form. Among the modalities of treatment, there are techniques for implantation of small fragments of fat. These are processed in a practical manner with a scalpel blade, which eliminates other types of recourse.

Some studies indicate that $45 \%$ of the volume of fatty tissue inserted can be absorbed after one year, following conventional implants obtained by aspiration. ${ }^{10}$ In scleroderma, inserts seem to last longer, as has been observed in cases relating to follow-up longer than one year (Figure 6). It is possible to suppose that implants obtained of fat fragments with septa of connective tissue will permit better surface contact with the receiving tissues, better nutrition and adaptation to the receptor layer. Treatment of the frontal region tends to be longer lasting than the chin region and infra orbital region. ${ }^{10}$ This could be explained by the detachment of the entire region which creates adequate layers for receiving the fragments. 


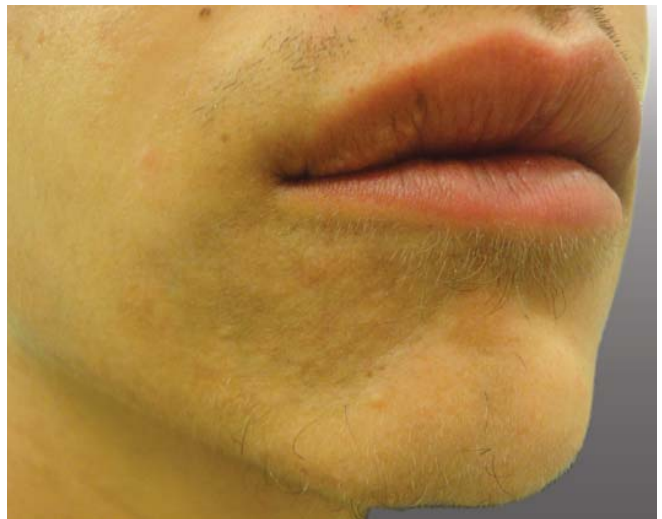

FIGURE 6: After filling, follow-up longer than one year

Contraindications for this procedure include coagulation disturbances, acute infections, chronic illness and alterations of lipid metabolism. The most common complications are ecchymoses, edemas, fat cysts, and rarely, vascular occlusive phenomenon.
Immediate results can be seen in post surgery, although it might be necessary to repeat the procedure to obtain the desired results.

None of the patients experienced major hematomas in the receptacle or donor regions.

It can be concluded that the technique described is a good therapeutic option in cases of localized lipodystrophy and especially facial scleroderma. In this region, there is low density in the subcutaneous tissue and major bone support.

The fat fragments with septa of connective tissue, extracted without the use of cannula and aligned to the detachment in the receptive region can produce lasting results, without the utilization of sophisticated recourses or the utilization of fillers which could reactivate the disease.

\section{REFERENCES}

1. Zwischenberger BA, Jacobe HT. A systematic review of morphea treatments and therapeutic algorithm. J Am Acad Dermatol. 2011;65:925-41.

2. Zancanaro PC, Isaac AR, Garcia LT, Costa IMC. Localized scleroderma in children: clinical, diagnostic and therapeutic aspects. An Bras Dermatol. 2009;84:161-72.

3. Sterodimas A, Huanquipaco JC, de Souza Filho S, Bornia FA, Pitanguy I. Autologous fat transplantation for the treatment of Parry-Romberg syndrome. J Plast Reconstr Aesthet Surg.. 2009;62:e424-6.

4. Kroft EB, Berkhof NJ, van de Kerkhof PC, Gerritsen RM, de Jong EM. Ultraviolet A phototherapy for sclerotic skin diseases: a systematic review. J Am Acad Dermatol. 2008;59:1017-30.

5. Kineston D, Kwan JM, Uebelhoer NS, Shumaker PR. Use of a fractional ablative 10.6$\mu \mathrm{m}$ carbon dioxide laser in the treatment of a morphea-related contracture. Arch Dermatol. 2011;147:1148-50.

6. Liu SW, Cohen GF. Idiopathic hemi-facial lipoatrophy treated with autologous fat transfer. J Cosmet Dermatol. 2010;9:226-9

7. Choksi AN, Orringer JS Linear morphea-induced atrophy treated with hyaluronic acid filler injections. Dermatol Surg. 2011;37:880-3.

8. Onesti MG, Troccola A, Scuderi N. Volumetric correction using poly-L-lactic acid in facial asymmetry: Parry Romberg syndrome and scleroderma. Dermatol Surg. 2009;35:1368-75.

9. Cavusoglu T, Yazici I, Vargel I, Karakaya El. Reconstruction of coup de sabre deformity (linear localized scleroderma) by using galeal frontalis muscle flap and demineralized bone matrix combination. J Craniofac Surg. 2011;22:257-8.

10. Roh MR, Jung JY, Chung KY. Autologous fat transplantation for depressed linear scleroderma-induced facial atrophic scars. Dermatol Surg. 2008;34:1659-65.

\author{
MAILING ADDRESS: \\ Tiago Pina Zanelato \\ Faculadade de Ciências Médicas - Dermatologia \\ Cidade Universitária "Zeferino Vaz" \\ 13083-970 - Distrito de Barão Geraldo - Campinas - SP \\ Brazil \\ E-mail: tizanelato@hotmail.com
}

How to cite this article: Zanelato TP, Marquesini G, Colpas PT, Magalhães RF, Moraes AM. Implantation of autologous fat globules in localized scleroderma and idiopathic lipoatrophy - report of five patients. An Bras Dermatol. 2013;88 (6 Suppl 1):S120-3. 